Classe $I V^{\mathrm{e}}$; LES AMPHIBIEns

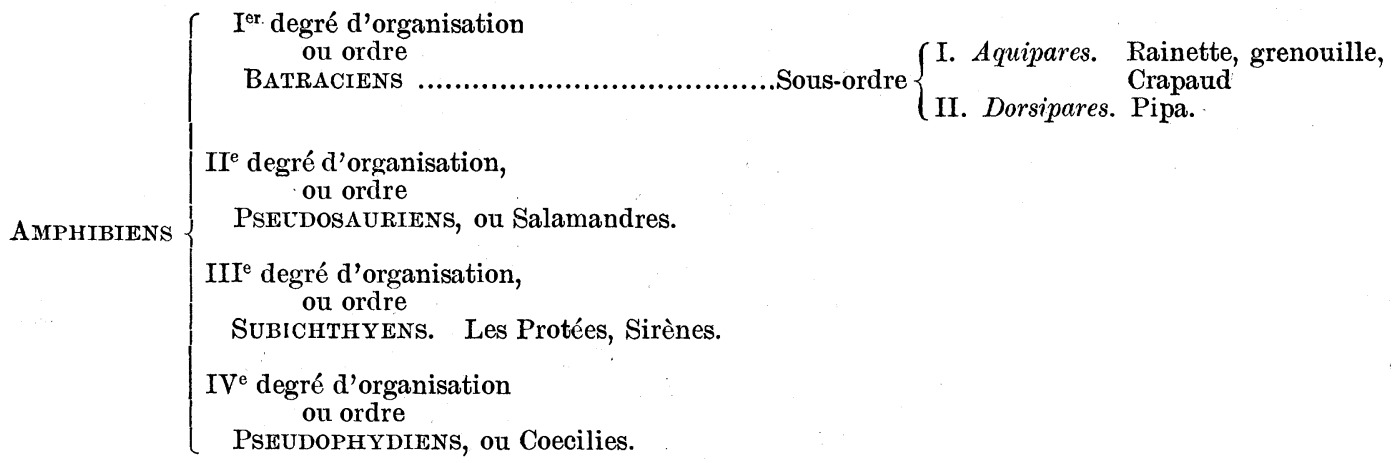

Three years later Latreille* used the Latin names Reptilia and Amphibia for de Blainville's classes Reptiles and Amphibiens, and these names ought to be used. Gray $\dagger$ in the same year, but later used the same names as distinct classes.

This name is used to-day all over Europe, France excepted.

Latreille's characters are the following:

P. 90. "Première Classe. REPTILES. REPTILIA.

"Ils ne respirent, et en tout temps, que par des poumous. Le cœur a deux ventricules et deux oreillettes. Les mâles ont une verge quelquefois double ou fourchue et s'accouplent. Plusieurs sont sujets á des mues complètes, ou se défont de leur peau, mais aucun n'éprouve de métamorphose. Le corps est plus souvent garni d'écailles ou emboîté; les pieds sont toujours armés d'ongles très-sensibles. La coque des oeufs est dure ou du moins coriace."

P. 103-14. "Seconde Classe. Amphibiens. Aмphibia.

"Ici les deux poumons sont accompagnés, soit dans le jeune âge, soit pendant toute la vie, de branchies. Le cœur n'a qu'un ventricule et qu'une oreilette, tant que les branchies persistent, un tronc artériel et dorsal tient lieu du ventricule qui manque, savoir la gauche il est remplacé, lorsqu' elles disparaissent, 'par une

* Latreille, Pierre André, Familles naturelles du régne animal, Paris, 1825, pp. 90-103.

† Gray, John Edward. A synopsis of the genera of Reptiles and Amphibia with a description of some new species. The Annals of Philosophy, New. Ser., Vol. X. London, Sept., 1825, pp. 194-213. artère dorsale. Les mâles n'ont point de verge. L'accouplement n'est que similué, c'est-à-dire qu'il ne consiste que dans de simples embrassements, durant lesquels les mâles fécondent les oeufs, á mesure qu'ils sortent. Les petits naissent sans pattes, et subissent de véritables métamorphoses. La peau est toujours nue, et les ongles des pieds sont nuls ou rarement sensibles. Les oeufs sont réunis, et leur coque est membraneuse. Ces animaux vivent pour la plupart dans les eaux ou les lieux humides."
February 14, 1897.
G. BAUR.

CORRECTION CONCERNING MR. RHOADS' USE OF THE NAME BASSARISCUS RAPTOR (BAIRD).

IN a recent paper in the Proceedings of the Biological Society of Washington* I quoted two statements, which were in part contradictory, from a paper by Mr. S. N. Rhoads respecting the proper name for the Oregon Bassarisk. In so doing I made a stupid blunder, for one of the statements in question was quoted by $\mathrm{Mr}$. Rhoads, whose own remarks in this particular were not inconsistent.

\section{Hart Merriam.}

\section{SCIENTIFIC LITERATURE.}

Report on Vital and Social Statistics in the United States at the Eleventh Census, 1890. Part II., Vital Statistics. Cities of 100,000 Population and Upward. By JoHn S. Billings, M.D. Washington, 1896 [Received May, 1897], pp. 1181.

Now that statistical studies of variation and *Proc. Biol. Soc. Wash., XI., 186, July 1, 1897. 